\title{
Relationship Between Depression and the Use of Mobile Technologies and Social Media Among Adolescents: Umbrella Review
}

Jorge Arias-de la Torre ${ }^{1,2,3,4^{*}}$, MSc, PhD; Elisa Puigdomenech ${ }^{3,5^{*}}$, MSc; Xavier García ${ }^{3}$, MSc; Jose M Valderas ${ }^{6}$, MD, $\mathrm{PhD}$, Prof Dr; Francisco Jose Eiroa-Orosa ${ }^{7}, \mathrm{MSc}, \mathrm{PhD}$; Tania Fernández-Villa ${ }^{4}, \mathrm{MSc}, \mathrm{PhD}$; Antonio J Molina ${ }^{4}$, MSc, $\mathrm{PhD}$; Vicente Martín ${ }^{2,4}, \mathrm{MD}, \mathrm{PhD}$, Prof Dr; Antoni Serrano-Blanco ${ }^{2,8}, \mathrm{MD}, \mathrm{PhD}$; Jordi Alonso ${ }^{2,9,10}$, MD, PhD, Prof Dr; Mireia Espallargues ${ }^{3,5}, \mathrm{MD}, \mathrm{PhD}$

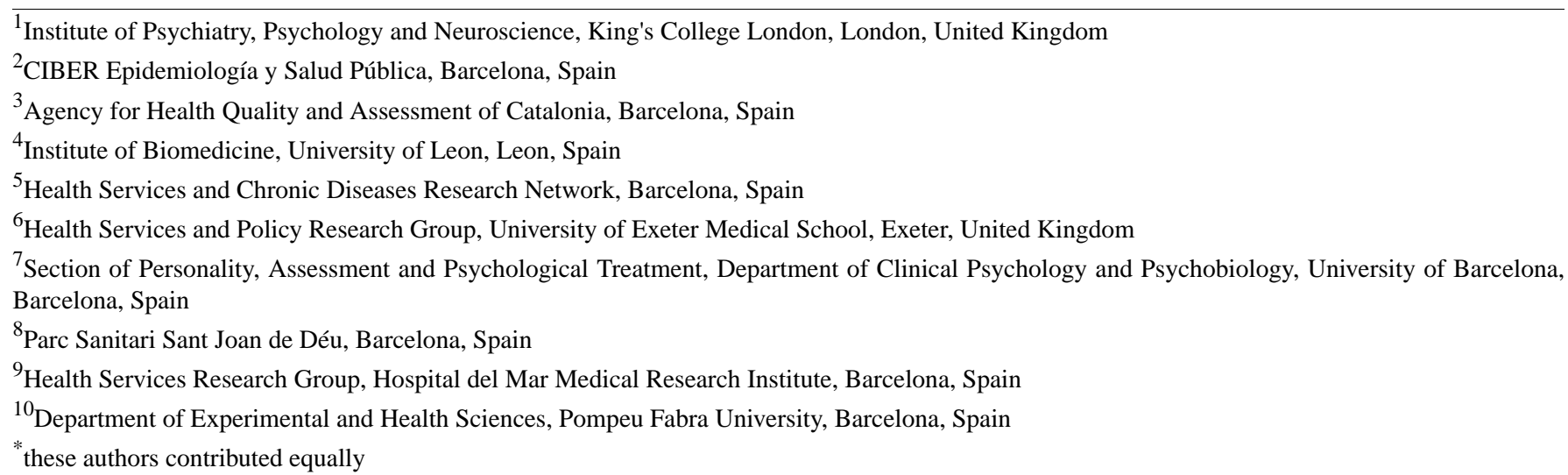

\section{Corresponding Author:}

Jorge Arias-de la Torre, $\mathrm{MSc}, \mathrm{PhD}$

Institute of Psychiatry, Psychology and Neuroscience

King's College London

16 De Crespigny Park

Denmark Hill campus

London, SE5 8AF

United Kingdom

Phone: 44634722677

Email: jorgeariasdelatorre@gmail.com

\section{Abstract}

Background: Despite the relevance of mobile technologies and social media (MTSM) for adolescents, their association with depressive disorders in this population remains unclear. While there are previous reviews that have identified the use of MTSM as a risk factor for developing depression, other reviews have indicated their possible preventive effect.

Objective: The aim of this review was to synthesize the current evidence on the association between MTSM use and the development or prevention of depressive disorders in adolescents.

Methods: An umbrella review was conducted using information published up to June 2019 from PubMed/MEDLINE, PsycINFO, Web of Science, and The Cochrane Library. Systematic reviews focusing on the adolescent population (up to 20 years old) and depression and its potential relationship with MTSM use were included. Screening of titles, abstracts, and full texts was performed. After selecting the reviews and given the heterogeneity of the outcome variables and exposures, a narrative synthesis of the results was carried out.

Results: The search retrieved 338 documents, from which 7 systematic reviews (3 meta-analyses) were selected for data extraction. There were 11-70 studies and 5582-46,015 participants included in the 7 reviews. All reviews included quantitative research, and 2 reviews also included qualitative studies. A statistically significant association between social media and developing depressive symptoms was reported in 2 reviews, while 5 reviews reported mixed results. 
Conclusions: Excessive social comparison and personal involvement when using MTSM could be associated with the development of depressive symptomatology. Nevertheless, MTSM might promote social support and even become a point of assistance for people with depression. Due to the mixed results, prospective research could be valuable for providing stronger evidence.

(J Med Internet Res 2020;22(8):e16388) doi: 10.2196/16388

\section{KEYWORDS}

mobile technologies and social media; depression; adolescents; review

\section{Introduction}

Depression is one of the most frequently occurring mental diseases worldwide, generating significant disability, dependence, and expenditure for health systems [1-4]. As shown in previous literature [5-10], adolescence is a particularly relevant period for developing depressive disorders. It should be noted that during adolescence, depressive symptomatology may be broader than in adulthood, manifesting itself through irritability, aggression, avoidance, or other behaviors in addition to the typical depressive behaviors [11]. Furthermore, during this period, young people can be especially influenced by sociocontextual factors, such as the use of mobile technologies and social media (MTSM). However, the effect of the exposure to these technologies on the development of depressive disorders in this age group remains unclear.

The use of MTSM has greatly increased over recent years, particularly since the 1990s, and adolescents can now be considered "digital natives," meaning they have been exposed to mobile devices and technologies like cellphones or tablets since birth [12-14]. This generalized exposure to social media implies a change in the way adolescents interact and communicate, naturally integrating the use of these technologies within their schemes of social perception $[15,16]$. Therefore, the use of MTSM could be particularly relevant, given the potential influence on adolescents' health, specifically their mental health and the development or prevention of depression.

One of the main uses of MTSM among adolescents is communication and social interaction with their peer groups through various means, including instant messaging apps (eg, WhatsApp and social networks). A few that stand out for their use in this population are Instagram, Snapchat, Twitter, and Facebook $[15,17]$. Using MTSM could prove beneficial in the sense that they may promote creativity, increase presence and social participation, and provide adolescents with quick access to different types of information, including that related to promoting healthy behaviors and habits $[12,13,18]$. However, the use of MTSM could also be related to problems like addictive internet behavior, absenteeism and failure in school, deterioration of family relationships and friendships, and different physical and mental health problems (including self-inflicted bodily impairment, eating disorders, and depression) [12,13,19]. Furthermore, MTSM use may also promote behavior that is damaging to health including, among other things, autolytic behavior, suicide, violence, and specific harmful behaviors such as cyberbullying, grooming, or sexting that are derived from the use of these technologies. Despite the abundance of literature, including systematic reviews and meta-analyses, most of the existing evidence is based on cross-sectional studies or surveys. Pooling or synthesizing data and using the broadest possible approach (eg, an umbrella review) could be valuable in determining the current knowledge on whether the use of MTSM is the cause or consequence of depressive symptomatology.

Although there is a wide variety of advantages and disadvantages that the use of new technologies can present for young people, the influence that their use could have on developing depression is unclear. Therefore, the aim of this review was to synthesize the evidence available on the association (intensity and direction) between depression and the use of MTSM in adolescents.

\section{Methods}

\section{Study Design and Information Sources}

An umbrella review on the association between the use of MTSM and depression was conducted, reported in accordance with the Preferred Reporting Items for Systematic Reviews and Meta-Analyses criteria (PRISMA), and registered in PROSPERO. The following databases were used as sources of information: PubMed/MEDLINE, PsycINFO, Web of Science, and Cochrane Reviews. All documents included in these databases published up to June 2019 were considered.

A search filter (Multimedia Appendix 1) was specifically designed to achieve the study objectives, taking into account pathology, target population, exposure (social network OR social media OR mobile phone OR * phone), and the languages in which the search was performed. After carrying out a preliminary search and observing the number of systematic reviews and meta-analyses found as well as the differences between the studies, an additional filter for study design was included. The filter was designed for PubMed/MEDLINE and adapted for other databases. The search strategy was based on previous studies in other areas with the intention of maximizing the number of identified documents [20,21]. In addition, the references in the final selected studies were used to identify other systematic reviews and meta-analyses, and key authors were contacted.

\section{Inclusion and Exclusion Criteria}

The PICO (Population, Intervention, Comparison, and Outcome) criteria were used to identify and include reviews in English that focused on the adolescent population (up to 20 years old), depression (in a broad sense, not specific diagnoses like major depressive disorder or dysthymia), and the possible relationship between depression and the use of MTSM.

Reviews that included studies with participants older than 20 years and studies that did not differentiate the effect by age 
group, if they included people older than 20 years, were excluded. Due to difficulties in extrapolating the results for the general adolescent population, studies on genetic or environmental factors and studies carried out in specific population groups, like those with specific characteristics or pathologies (eg, attention deficit hyperactivity disorder), were excluded. Finally, studies focusing on treatments administered through an electronic device or the internet as well as opinion articles and proposals with theoretical or conceptual frameworks that were not based on a systematic literature review or meta-analysis were also excluded.

\section{Review Process}

A review of titles, abstracts, and full texts was carried out independently by two expert reviewers (JAT and XG), and discrepancies were resolved by a third researcher (EP) with expertise in conducting systematic reviews. After study selection, a synthesis of the evidence obtained from the 7 selected reviews was carried out. The quality of each review was considered by taking into account the quality of the studies evaluated and the tools used to assess the studies. Owing to heterogeneity in the characteristics of the studies and in the presentation of outcome variables and exposures, a meta-analysis of the results was not possible; therefore, a narrative synthesis of the results was carried out. Information from the included reviews was extracted and summarized in 2 tables of evidence [22].

\section{Results}

The search retrieved 338 articles (154 from PubMed, 80 from the Cochrane Library, 41 from PsycINFO, 55 from Web of Science, and 8 from a manual search). After removing 34 duplicates, a total of 304 studies were deemed potentially eligible. The full text of 20 documents was reviewed, and 13 articles were excluded ( 7 non-systematic or narrative reviews, 5 documents based on other pathologies, and 1 for the inability to differentiate between results reported for adults versus adolescents). Finally, 7 systematic reviews were selected for data extraction (Figure 1) [21,23-30].

Figure 1. Flow diagram of the review process.

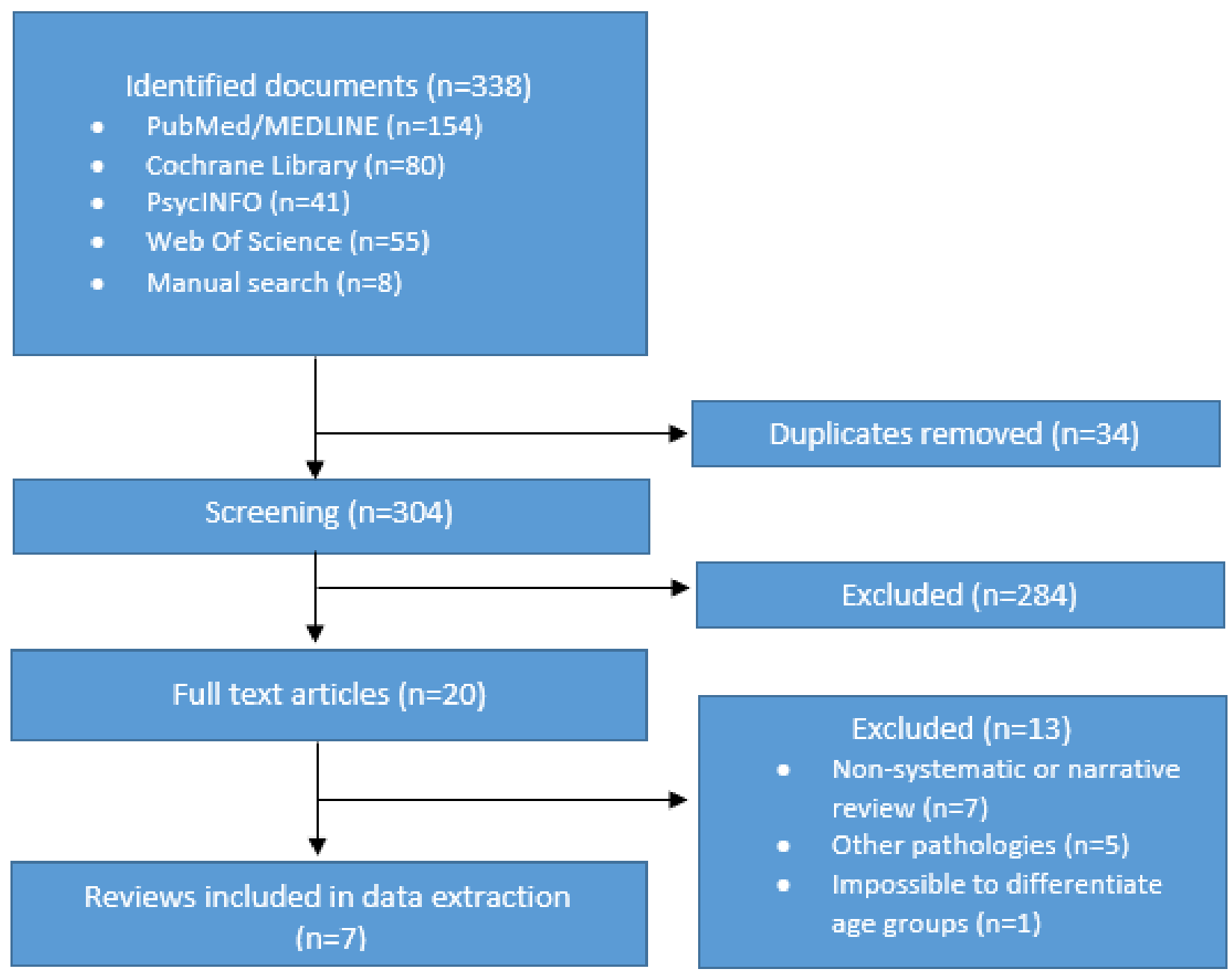

Table 1 shows the characteristics of the included systematic reviews, all of which were published between 2014 and 2019. In these reviews, PsycINFO, Medline, and CINAHL databases were searched most frequently. Two reviews explored dissertations and thesis databases [25,31]. Most reviews assessed the relationship between depression and use of social networks in general $[23,25,26,28]$ or problematic Facebook use in particular [31]. One study by $\mathrm{Wu}$ et al [29] reviewed the association between internet use in general and depression. Wellbeing, anxiety, and loneliness were also assessed in 2 
reviews [26,29]. There were 11-70 studies and 5582-46,015 participants included in the reviews. Most studies included in the reviews were quantitative and used cross-sectional and survey-based data. While 2 reviews used specific criteria developed by the authors to assess the quality of studies [29,31], 4 used validated assessment tools [21,23,26,28], and 1 did not specify the tool [25]. In addition, 2 meta-analyses were included $[25,31]$.

Table 2 shows the results of the included reviews. Four studies were undertaken specifically with adolescents (age range 10-21 years) $[21,23,28,29]$. Seabrook et al [26] also included adults in their review ( 2 studies with adults and 18 studies with the general population), and Marino et al [31] reported a mean age range of 16.5-32.4 years. While 2 reviews reported a positive association between depressive symptoms and social media use (overall random effects pooled estimate: $r=0.13$, 95\% CI
0.05-0.2) [23] and problematic Facebook use ( $r=0.34,95 \% \mathrm{CI}$ $0.28-0.39$ ) [31], the other 5 reviews reported mixed associations between social media use and depression. Keles et al [28] reported a positive association for the relationships between time spent on social media and depression and between social media addiction and depression. Two reviews reported a gender influence with mixed effects [23]. McCrae et al [23] found that 4 studies reported girls having more depressive symptoms related to social media use and 2 studies showed that boys were more likely to show depressive symptoms. The rest of the studies included in their review did not show a gender effect. In the review by Keles et al [28], one study found that social media might have negative effects in girls but could be considered a positive leisure activity for boys, and 2 studies did not show gender effects. In addition to mixed results for the associations between social media use and wellbeing, associations with anxiety and loneliness were also found [21,26,29]. 
Table 1. Characteristics of the included reviews.

\begin{tabular}{|c|c|c|c|c|c|c|}
\hline Author (year) & $\begin{array}{l}\text { Objective of the re- } \\
\text { view }\end{array}$ & Databases searched & $\begin{array}{l}\text { Number of } \\
\text { studies includ- } \\
\text { ed }\end{array}$ & $\begin{array}{l}\text { Number of partici- } \\
\text { pants }\end{array}$ & $\begin{array}{l}\text { Quality assessment of } \\
\text { studies included }\end{array}$ & Methodology \\
\hline $\begin{array}{l}\text { Best et al } \\
\text { (2014) [21] }\end{array}$ & $\begin{array}{l}\text { To assess the impact } \\
\text { of social media use on } \\
\text { mental wellbeing in } \\
\text { young people }\end{array}$ & $\begin{array}{l}\text { ASSIA }^{\mathrm{a}} \text {, Communica- } \\
\text { tion abstracts, } \\
\text { CINAHL, ERIC }^{\mathrm{b}} \text {, } \\
\text { Medline (Ovid), } \\
\text { PsycINFO (Ovid), } \\
\text { SCOPUS, SSCI }^{\mathrm{c}}\end{array}$ & 43 & $N S^{d}$ & $\begin{array}{l}\text { Specific criteria devel- } \\
\text { oped by the authors of } \\
\text { the review }\end{array}$ & $\begin{array}{l}32 \text { quantitative, } 9 \\
\text { qualitative, } 2 \text { mixed } \\
\text { methods or others }\end{array}$ \\
\hline $\begin{array}{l}\text { Wu et al } \\
\text { (2016) [29] }\end{array}$ & $\begin{array}{l}\text { To examine the associ- } \\
\text { ation between internet } \\
\text { use, social connection, } \\
\text { and levels of depres- } \\
\text { sion, anxiety, and } \\
\text { loneliness }\end{array}$ & $\begin{array}{l}\text { CINAHL, ERIC, Psy- } \\
\text { chology and Behavioral } \\
\text { Series Collection, Sci- } \\
\text { ence and Technology } \\
\text { Collection, EBSCO so- } \\
\text { cial sciences database }\end{array}$ & 12 & 5582 & $\begin{array}{l}\text { Specific criteria devel- } \\
\text { oped by the authors of } \\
\text { the review }\end{array}$ & $\begin{array}{l}9 \text { quantitative (all } \\
\text { cross-sectional), } 1 \\
\text { mixed methods, and } \\
2 \text { qualitative }\end{array}$ \\
\hline $\begin{array}{l}\text { Seabrook et al } \\
\text { (2016) [26] }\end{array}$ & $\begin{array}{l}\text { To examine the rela- } \\
\text { tionship between the } \\
\text { use of social networks } \\
\text { and depression and } \\
\text { anxiety as well as } \\
\text { links with wellbeing } \\
\text { and potential media- } \\
\text { tors and moderators of } \\
\text { these relationships }\end{array}$ & $\begin{array}{l}\text { PsycINFO, MEDLINE } \\
\text { (Ovid), Scopus, IEEE } \\
\text { Xplore, CINAHL, Edu- } \\
\text { cation Resources Infor- } \\
\text { mation Center, SSCI, } \\
\text { Communication and } \\
\text { Mass Media Complete }\end{array}$ & 70 & 46,015 & $\begin{array}{l}\text { Adaptation of the } \\
\text { Cochrane bias tool }\end{array}$ & NS \\
\hline $\begin{array}{l}\text { McCrae et al } \\
(2017) \text { [23] }\end{array}$ & $\begin{array}{l}\text { To examine the associ- } \\
\text { ation between social } \\
\text { media (websites used } \\
\text { primarily for social } \\
\text { interaction) and de- } \\
\text { pression or depressive } \\
\text { symptoms }\end{array}$ & $\begin{array}{l}\text { Medline, PsycINFO, } \\
\text { EMBASE }\end{array}$ & 11 & 12,646 & $\begin{array}{l}\text { Robins- } \mathrm{I}^{\mathrm{e}} \text {, } \\
\text { Cochrane Collabora- } \\
\text { tion Methods Group } \\
\text { Tool to assess risk of } \\
\text { bias in cohort studies }\end{array}$ & $\begin{array}{l}\text { Quantitative (7 } \\
\text { cross-sectional, } \\
4 \text { longitudinal) }\end{array}$ \\
\hline $\begin{array}{l}\text { Marino et al } \\
\text { (2018) [31] }\end{array}$ & $\begin{array}{l}\text { To examine the associ- } \\
\text { ation between Face- } \\
\text { book use (problemat- } \\
\text { ic, abusive, overuse, } \\
\text { compulsive) and psy- } \\
\text { chological disorders } \\
\text { in adolescents and } \\
\text { young adults }\end{array}$ & $\begin{array}{l}\text { PsycINFO, PubMed, } \\
\text { Scopus, ResearchGate, } \\
\text { Google Scholar, Disser- } \\
\text { tation Abstracts Interna- } \\
\text { tional, Pro-Quest Disser- } \\
\text { tations and Theses } \\
\text { Open, Open Access } \\
\text { Theses and Disserta- } \\
\text { tions }\end{array}$ & 23 & 13,929 & $\begin{array}{l}\text { Specific criteria devel- } \\
\text { oped by the authors of } \\
\text { the review }\end{array}$ & Quantitative \\
\hline $\begin{array}{l}\text { Keles et al } \\
\text { (2019) [28] }\end{array}$ & $\begin{array}{l}\text { To examine the influ- } \\
\text { ence of using social } \\
\text { networks on depres- } \\
\text { sion in adolescents }\end{array}$ & $\begin{array}{l}\text { PsycINFO, Medline, } \\
\text { EMBASE, CINAHL, } \\
\text { SSCI }\end{array}$ & 13 & 21,231 & $\mathrm{NIH}^{\mathrm{f}}$ & $\begin{array}{l}\text { Quantitative (12 } \\
\text { cross-sectional, } 1 \\
\text { longitudinal) }\end{array}$ \\
\hline $\begin{array}{l}\text { Yoon et al } \\
\text { (2019) [25] }\end{array}$ & $\begin{array}{l}\text { To examine the rela- } \\
\text { tionship between the } \\
\text { use of social network- } \\
\text { ing sites and depres- } \\
\text { sion }\end{array}$ & $\begin{array}{l}\text { PsycINFO, PubMed, } \\
\text { ProQuest Dissertations } \\
\text { \& Theses Global }\end{array}$ & 55 & 22,099 & NS & Quantitative \\
\hline
\end{tabular}

${ }^{a}$ ASSIA: Applied Social Sciences Index and Abstracts.

${ }^{b}$ ERIC: Education Resources Information Center.

${ }^{\mathrm{c}}$ SSCI: Social Sciences Citation Index.

${ }^{\mathrm{d}} \mathrm{NS}$ : not specified.

${ }^{\mathrm{e}}$ Risk of bias tool to assess nonrandomized studies of interventions.

${ }^{f}$ NIH: National Institutes of Health Quality Assessment Tool for Observational Cohort and Cross-Sectional Studies. 
Table 2. Results of the included reviews.

\begin{tabular}{|c|c|c|c|c|c|}
\hline Author (year) & $\begin{array}{l}\text { Sample (num- } \\
\text { ber of studies) } \\
\text { or age (years) }\end{array}$ & $\begin{array}{l}\text { Use of } \\
\text { MTSM }^{\mathrm{a}}\end{array}$ & Association(s) & Gender effect & Other associations \\
\hline $\begin{array}{l}\text { Best et al } \\
(2014)[21]\end{array}$ & $\begin{array}{l}\text { Adolescents } \\
\text { (age range not } \\
\text { specified) }\end{array}$ & $\begin{array}{l}\text { Communica- } \\
\text { tion and social } \\
\text { interaction }\end{array}$ & $\begin{array}{l}\text { Mixed results in the association } \\
\text { of social media technologies } \\
\text { and depression }\end{array}$ & $\begin{array}{l}\text { Does not distinguish nor consider } \\
\text { this factor }\end{array}$ & $\begin{array}{l}\text { Mixed results on self-esteem, } \\
\text { social support, loneliness, and } \\
\text { cyberbullying }\end{array}$ \\
\hline $\begin{array}{l}\text { Wu et al } \\
\text { (2016) [29] }\end{array}$ & $10-21$ & $\begin{array}{l}\text { Use of internet } \\
\text { and related } \\
\text { technologies }\end{array}$ & $\begin{array}{l}1 \text { of } 5 \text { studies found that social } \\
\text { media technology use can lead } \\
\text { to depressive feelings; } 4 \text { of } 5 \\
\text { studies did not find an associa- } \\
\text { tion. }\end{array}$ & $\begin{array}{l}\text { Takes into account the popula- } \\
\text { tion of the studies ( } 10 \text { mixed } \\
\text { gender, } 2 \text { only boys), but not in } \\
\text { terms of the results }\end{array}$ & $\begin{array}{l}\text { Mixed results on social connec- } \\
\text { tivity, anxiety, and loneliness }\end{array}$ \\
\hline $\begin{array}{l}\text { Seabrook et al } \\
\text { (2016) [26] }\end{array}$ & $\begin{array}{l}\text { Adolescents } \\
\text { (8), young } \\
\text { adults (40), } \\
\text { general popula- } \\
\text { tion (18), } \\
\text { adults (2), } \\
\text { clinical depres- } \\
\text { sion (1), oth- } \\
\text { ers (1) }\end{array}$ & $\begin{array}{l}\text { Use of social } \\
\text { networks }\end{array}$ & $\begin{array}{l}\text { Mixed results: positive interac- } \\
\text { tions, social support, and con- } \\
\text { nectivity in social networks re- } \\
\text { lated with lower levels of de- } \\
\text { pression; negative interactions } \\
\text { and social comparison related } \\
\text { with higher levels of depression }\end{array}$ & $\begin{array}{l}\text { Not considered as a variable in } \\
\text { the included studies but consid- } \\
\text { ered in the discussion of the re- } \\
\text { sults }\end{array}$ & $\begin{array}{l}\text { Mixed results for anxiety and } \\
\text { wellbeing }\end{array}$ \\
\hline $\begin{array}{l}\text { McCrae et al } \\
\text { (2017) [23] }\end{array}$ & $\begin{array}{l}10-17 \text { (one } \\
\text { study included } \\
\text { "high school } \\
\text { students" but } \\
\text { did not specify } \\
\text { age range) }\end{array}$ & $\begin{array}{l}\text { Use of social } \\
\text { media }\end{array}$ & $\begin{array}{l}\text { Small but statistically signifi- } \\
\text { cant overall correlation between } \\
\text { social media use and depressive } \\
\text { symptoms }\end{array}$ & $\begin{array}{l}4 \text { studies found that girls had } \\
\text { more depressive symptoms relat- } \\
\text { ed to social media use; } 2 \text { studies } \\
\text { showed that boys were more } \\
\text { likely to show depressive symp- } \\
\text { toms; the rest showed no gender } \\
\text { differences }\end{array}$ & $\mathrm{NS}^{\mathrm{b}}$ \\
\hline $\begin{array}{l}\text { Marino et al } \\
\text { (2018) [31] }\end{array}$ & $\begin{array}{l}\text { Mean 21.9 } \\
(\text { SD 3.97); } \\
16.5-32.4 \\
\text { (mean age } \\
\text { range) }\end{array}$ & $\begin{array}{l}\text { Problematic } \\
\text { Facebook use }\end{array}$ & $\begin{array}{l}\text { Association between problemat- } \\
\text { ic Facebook use and depression }\end{array}$ & $\begin{array}{l}\text { Proportion of girls }(60.7 \%) \text { did } \\
\text { not moderate the effect }\end{array}$ & $\begin{array}{l}\text { Correlation between problemat- } \\
\text { ic Facebook use and psycholog- } \\
\text { ical distress was greater in } \\
\text { samples with a higher mean } \\
\text { age. }\end{array}$ \\
\hline $\begin{array}{l}\text { Keles et al } \\
\text { (2019) [28] }\end{array}$ & $13-18$ & $\begin{array}{l}\text { Time spent, } \\
\text { activity (quali- } \\
\text { ty and quanti- } \\
\text { ty of user's } \\
\text { engagement } \\
\text { and interac- } \\
\text { tion with so- } \\
\text { cial media sets } \\
\text { and other } \\
\text { users), invest- } \\
\text { ment (time } \\
\text { spent on social } \\
\text { media), addic- } \\
\text { tion (state of } \\
\text { being depen- } \\
\text { dent on social } \\
\text { media) }\end{array}$ & $\begin{array}{l}\text { Time spent: } 1 \text { study showed } \\
\text { association, } 1 \text { did not, } 2 \text { did not } \\
\text { find association; activity: } 2 \\
\text { studies showed positive associ- } \\
\text { ation, and } 1 \text { did not; invest- } \\
\text { ment: } 3 \text { studies showed associ- } \\
\text { ation; addiction: } 3 \text { studies } \\
\text { showed positive association }\end{array}$ & $\begin{array}{l}4 \text { studies measured the effect of } \\
\text { gender between social media-re- } \\
\text { lated variables and mental health } \\
\text { outcomes. } 2 \text { studies did not find } \\
\text { effects on gender, while } 1 \text { found } \\
\text { that social media might have } \\
\text { negative effects in girls and can } \\
\text { be considered a positive leisure } \\
\text { activity for boys. Facebook had } \\
\text { a negative impact on both gen- } \\
\text { ders. }\end{array}$ & $\begin{array}{l}\text { There was a relationship be- } \\
\text { tween age, heavy social media } \\
\text { use, and negatively internaliz- } \\
\text { ing symptoms. Younger adoles- } \\
\text { cents were more likely to expe- } \\
\text { rience internalizing symptoms } \\
\text { (being anxious, depressed, } \\
\text { withdrawn). Most studies high- } \\
\text { lighted the fact that the relation- } \\
\text { ships observed were too com- } \\
\text { plex for straightforward state- } \\
\text { ments and mediating and mod- } \\
\text { erating factors should be taken } \\
\text { into account. }\end{array}$ \\
\hline $\begin{array}{l}\text { Yoon et al } \\
\text { (2019) [25] }\end{array}$ & $\begin{array}{l}17.83-24.76 \\
\text { (mean age } \\
\text { range) }\end{array}$ & $\begin{array}{l}\text { Use of SNS": } \\
\text { time spent and } \\
\text { SNS check- } \\
\text { ing; social } \\
\text { comparison } \\
\text { and "upward" } \\
\text { social compar- } \\
\text { ison }\end{array}$ & $\begin{array}{l}\text { Positive statistically significant } \\
\text { difference between depression } \\
\text { and time spent on its use, fre- } \\
\text { quency of use, social compari- } \\
\text { son, and "upwards" comparison }\end{array}$ & No difference & NS \\
\hline
\end{tabular}

${ }^{a}$ MTSM: mobile technologies and social media.

${ }^{\mathrm{b}} \mathrm{NS}$ : not specified.

${ }^{\mathrm{c}} \mathrm{SNS}$ : social networking sites. 


\section{Discussion}

The results from the included reviews suggest that social comparison and excessive personal involvement by adolescents when using MTSM could be related to the development of depressive symptoms. However, the use of MTSM when properly adapted could also promote healthy behaviors, improve social support, and even become a point of access of information and help for adolescents at risk of depression.

Both mobile technologies and social media are important aspects of how we interact today and have transformed the way in which the generations adopting MTSM and digital natives communicate $[18,32]$. The use of MTSM presents great opportunities in terms of creativity and ways of learning but can also entail certain risks such as isolation and restricted social interaction. Despite this, studying the possible effects on health, specifically on depression, of adolescents using MTSM is a relatively recent phenomenon. As such, it should be noted that all reviews included in this study were published in the last 5 years.

The evidence from different studies published until now, and particularly since 2017 , suggests a positive and significant association between some aspects of social media use and the presence of depressive symptoms among adolescents [23-25]. Two relevant factors that increased the magnitude of this association were the problematic use of social networks and excessive social comparison [23-25]. There is less relevant evidence pointing to other factors related to the undesirable effects of social networks, like a higher level of personal involvement on the networks, defined as the degree of exposure and personal information that adolescents publish on networks or the exposure to content that promotes depressive-like behaviors [27,28]. Finally, it is worth mentioning that a high volume of studies indicating associations between the use of social networks and other undesirable effects like anxiety, harassment, or internet or smartphone addiction was identified [21,26,28-30]. Regarding internet addiction, the total usage time, frequency of consultation, and other variables related to excess use, both in frequency and time, may be more relevant than the variables found in this study, which focus specifically on depressive symptomatology.

It should be noted that the impact of the identified factors, particularly of social comparison, on the development of depression might be affected by the level of the welfare and wealth of the family [7-12]. Accordingly, those who are from families with lower socioeconomic status might have a high risk of developing depression when exposed to more wealthy people. In addition, these factors might be particularly related to the development of some specific depressive symptoms (eg, sleep problems or diminished ability to think or concentrate). Further longitudinal research focused on specific factors, like family environment, and accounting for specific depressive symptoms might be valuable in preventing the potential development of depression in MTSM users.

Emphasizing the fact that social networks do not necessarily imply a negative impact on young people's moods, other studies have described the desirable effects that social media use might have $[12,33,34]$. In this sense and in line with the results of these studies, the evidence found in this study suggests that social networks can promote social support and even become points of access to information and help for people with depressive disorders [26,27]. As suggested, the use of MTSM under adult supervision might be related to promoting healthy use of MTSM, as well as preventing possible negative consequences that arise like depressive symptomatology [35]. In addition, the use of new technologies could facilitate young people's connection with multiple social circles, reducing their perception of loneliness or isolation [29].

Some studies identified differences between boys and girls in the impact that social networks have on developing depressive symptoms. Previous research proposed [30] that the prevalence of intensive use of mobile technologies might be greater in women than in men. Furthermore, the use of mobile technologies could be mainly for relational purposes among teenage women and instrumental or for leisure among teenage men, making women more likely to be exposed to the effects of social networks [23,24,28]. Although the meta-analysis by McCrae et al [23] did not determine a theoretical basis for the potential differences, there are some studies included within the analysis and 1 study included in the systematic review by Keles et al [28] that show a greater correlation between social comparison and depression in women. This might allow us to hypothesize that focusing preventive measures on social comparison in adolescent women and on leisure platforms, like gaming platforms, in adolescent men could be effective in preventing the undesirable effects of social networks and mobile technology use among adolescents. Further research aimed at proving this hypothesis could be valuable.

Several limitations of the current study deserve discussion. First is the lack of longitudinal or experimental evidence in relation to the use of social networks and mobile technologies and their impact on depressive symptomatology. In this sense, most of the studies included in the literature reviewed were cross-sectional and survey-based, precluding the establishment of causal relationships between variables. As such, it is difficult to determine whether the use of social networks and mobile technologies is the cause or consequence of depressive symptomatology, and further longitudinal studies to test these hypotheses could be valuable. We should also mention the possible heterogeneity of health problems and of the patterns made or activities observed in the studies when using MTSM. While some were focused on clinical depression diagnosed by a professional, others were focused on less valid depression criteria, which could limit the comparability of the reviews included. Furthermore, some of the reviews included internet addicts. Despite this, the broad aim of this review was to determine the relationship between depressive disorders and the use of MTSM, which we consider completed through the studies included in this article, independent of the depression metrics and specific populations used in the selected reviews.

Another limitation is the lack of solid evidence or a conceptual framework on the specific behaviors, like online gaming or uploading photos to social networks, that could be related to depressive symptomatology. This lack of evidence may be due to the relative novelty of the social network phenomenon and 
the shortage of valid, reliable health information pertaining to it. However, certain behaviors that could be related to the development of depression as a protective factor were identified, like searching for help or preventive information. Another limitation is that only reviews in English were included, possibly omitting scientific literature written in other languages. Finally, we should mention the limitation of having actively excluded studies on cyberbullying, addiction to new technologies, or other symptoms and harmful behaviors that could be part of or related to a depressive disease. Given their importance and the abundance of evidence on these phenomena, these behaviors deserve to be treated as separate entities, and, as previous research suggests, specific reviews should be performed on these behaviors $[21,26]$.
In conclusion, our study shows that, during adolescence, the use of MTSM and particularly excessive social comparison and personal involvement when using it could be associated with developing depressive symptomatology. Nevertheless, the adaptive use of MTSM could also help prevent the development of depression, promote social support, and even become a point of information access and help for people with depressive disorders or symptoms. Other variables, like time spent on the internet and social networks, the frequency of consultation, and factors related to excess use, both in frequency and in time, may be more relevant in developing other problems like internet addiction. Due to the heterogeneity in methodology and the contradictory findings from the reviews included in this umbrella review, prospective research, especially longitudinal cohort studies and randomized controlled trials, could be valuable in providing stronger evidence on these relationships.

\section{Acknowledgments}

We acknowledge Antoni Parada and Kayla Smith for their support and CIBER Epidemiology and Public Health (CIBERESP) for its funding.

\section{Conflicts of Interest}

None declared.

\section{Multimedia Appendix 1}

PubMed/MEDLINE filter. [DOCX File, 12 KB-Multimedia Appendix 1]

\section{References}

1. GBD 2016 Disease and Injury Incidence and Prevalence Collaborators. Global, regional, and national incidence, prevalence, and years lived with disability for 328 diseases and injuries for 195 countries, 1990-2016: a systematic analysis for the Global Burden of Disease Study 2016. The Lancet 2017 Sep;390(10100):1211-1259. [doi: 10.1016/S0140-6736(17)32154-2]

2. Moussavi S, Chatterji S, Verdes E, Tandon A, Patel V, Ustun B. Depression, chronic diseases, and decrements in health: results from the World Health Surveys. The Lancet 2007 Sep;370(9590):851-858. [doi: 10.1016/S0140-6736(07)61415-9]

3. Vigo D, Thornicroft G, Atun R. Estimating the true global burden of mental illness. The Lancet Psychiatry 2016 Feb;3(2):171-178. [doi: 10.1016/s2215-0366(15)00505-2]

4. Arias-de la Torre J, Vilagut G, Martín V, Molina AJ, Alonso J. Prevalence of major depressive disorder and association with personal and socio-economic factors. Results for Spain of the European Health Interview Survey 2014-2015. J Affect Disord 2018 Oct 15;239:203-207. [doi: 10.1016/j.jad.2018.06.051] [Medline: $\underline{30014961]}$

5. Thapar A, Collishaw S, Pine DS, Thapar AK. Depression in adolescence. The Lancet 2012 Mar;379(9820):1056-1067. [doi: 10.1016/S0140-6736(11)60871-4]

6. Costello EJ, Mustillo S, Erkanli A, Keeler G, Angold A. Prevalence and development of psychiatric disorders in childhood and adolescence. Arch Gen Psychiatry 2003 Aug 01;60(8):837-844. [doi: 10.1001/archpsyc.60.8.837] [Medline: 12912767]

7. Arias-de la Torre J, Fernández-Villa T, Molina A, Amezcua-Prieto C, Mateos R, Cancela J, et al. Psychological Distress, Family Support and Employment Status in First-Year University Students in Spain. Int J Environ Res Public Health 2019 Apr 04;16(7):1209 [FREE Full text] [doi: 10.3390/ijerph16071209] [Medline: 30987309]

8. Arnett JJ. Emerging adulthood. A theory of development from the late teens through the twenties. Am Psychol 2000 May;55(5):469-480. [Medline: 10842426]

9. Harris A. Mental health and moving from school to further and higher education. London, England: Center for Mental Health; 2019.

10. Johnson D, Dupuis G, Piche J, Clayborne Z, Colman I. Adult mental health outcomes of adolescent depression: A systematic review. Depress Anxiety 2018 Aug 07;35(8):700-716. [doi: 10.1002/da.22777] [Medline: 29878410]

11. Lewis M, Rudolph K, editors. Handbook of Developmental Psychopathology, Third Edition. New York, NY: Springer; 2014.

12. Hur J, Gupta M. Growing up in the Web of Social Networking: Adolescent Development and Social Media. APS 2013 Aug 01;3(3):233-244. [doi: 10.2174/2210676611303030004] 
13. Pantic I. Online social networking and mental health. Cyberpsychol Behav Soc Netw 2014 Oct;17(10):652-657 [FREE Full text] [doi: 10.1089/cyber.2014.0070] [Medline: 25192305]

14. Sánchez-Martínez M, Otero A. Factors associated with cell phone use in adolescents in the community of Madrid (Spain). Cyberpsychol Behav 2009 Apr;12(2):131-137. [doi: 10.1089/cpb.2008.0164] [Medline: 19072078]

15. Smith A, Anderson M. Social Media Use 2018: Demographics and Statistics | Pew Research Center. Pew Res Cent Internet Technol 2018. [doi: 10.1007/978-1-349-70154-4 163]

16. Rich M. Moving from child advocacy to evidence-based care for digital natives. JAMA Pediatr 2014 May;168(5):404-406. [doi: 10.1001/jamapediatrics.2014.55] [Medline: 24687218]

17. Richards D, Caldwell PH, Go H. Impact of social media on the health of children and young people. J Paediatr Child Health 2015 Nov 26;51(12):1152-1157. [doi: 10.1111/jpc.13023]

18. Reid Chassiakos YL, Radesky J, Christakis D, Moreno M, Cross C, Council on Communications and Media. Children and Adolescents and Digital Media. Pediatrics 2016 Nov;138(5):e1-e18 [FREE Full text] [doi: 10.1542/peds.2016-2593] [Medline: 27940795]

19. Hussain Z, Griffiths MD. Problematic Social Networking Site Use and Comorbid Psychiatric Disorders: A Systematic Review of Recent Large-Scale Studies. Front Psychiatry 2018 Dec;9:686 [FREE Full text] [doi: 10.3389/fpsyt.2018.00686] [Medline: 30618866$]$

20. Terwee CB, Jansma EP, Riphagen II, de Vet HCW. Development of a methodological PubMed search filter for finding studies on measurement properties of measurement instruments. Qual Life Res 2009 Aug 27;18(8):1115-1123. [doi: 10.1007/s11136-009-9528-5]

21. Best P, Manktelow R, Taylor B. Online communication, social media and adolescent wellbeing: A systematic narrative review. Children and Youth Services Review 2014 Jun;41:27-36. [doi: 10.1016/j.childyouth.2014.03.001]

22. Smith V, Devane D, Begley CM, Clarke M. Methodology in conducting a systematic review of systematic reviews of healthcare interventions. BMC Med Res Methodol 2011 Feb 03;11(1):15 [FREE Full text] [doi: 10.1186/1471-2288-11-15] [Medline: 21291558]

23. McCrae N, Gettings S, Purssell E. Social Media and Depressive Symptoms in Childhood and Adolescence: A Systematic Review. Adolescent Res Rev 2017 Mar 2;2(4):315-330. [doi: 10.1007/s40894-017-0053-4]

24. Camporesi E, Vezzani G, Zanon V, Manelli D, Enten G, Quartesan S, et al. Review on hyperbaric oxygen treatment in femoral head necrosis. UHM 2017 Nov 1;44(6):497-508. [doi: 10.22462/11.12.2017.1]

25. Yoon S, Kleinman M, Mertz J, Brannick M. Is social network site usage related to depression? A meta-analysis of Facebook-depression relations. Journal of Affective Disorders 2019 Apr;248:65-72. [doi: 10.1016/j.jad.2019.01.026]

26. Seabrook EM, Kern ML, Rickard NS. Social Networking Sites, Depression, and Anxiety: A Systematic Review. JMIR Ment Health 2016 Nov 23;3(4):e50. [doi: 10.2196/mental.5842]

27. Memon AM, Sharma SG, Mohite SS, Jain S. The role of online social networking on deliberate self-harm and suicidality in adolescents: A systematized review of literature. Indian J Psychiatry 2018;60(4):384-392 [FREE Full text] [doi: 10.4103/psychiatry.IndianJPsychiatry 414 17] [Medline: 30581202 ]

28. Keles B, McCrae N, Grealish A. A systematic review: the influence of social media on depression, anxiety and psychological distress in adolescents. International Journal of Adolescence and Youth 2019 Mar 21;25(1):79-93. [doi: $10.1080 / 02673843.2019 .1590851]$

29. Wu YJ, Outley C, Matarrita-Cascante D, Murphrey TP. A Systematic Review of Recent Research on Adolescent Social Connectedness and Mental Health with Internet Technology Use. Adolesc Res Rev 2016;1(2):153-162. [doi: 10.1007/s40894-015-0013-9]

30. Marchant A, Hawton K, Stewart A, Montgomery P, Singaravelu V, Lloyd K, et al. A systematic review of the relationship between internet use, self-harm and suicidal behaviour in young people: The good, the bad and the unknown. PLoS ONE 2017 Aug 16;12(8):e0181722. [doi: 10.1371/journal.pone.0181722]

31. Marino C, Gini G, Vieno A, Spada MM. The associations between problematic Facebook use, psychological distress and well-being among adolescents and young adults: A systematic review and meta-analysis. Journal of Affective Disorders 2018 Jan;226:274-281. [doi: 10.1016/j.jad.2017.10.007]

32. Moreno MA, Goniu N, Moreno PS, Diekema D. Ethics of social media research: common concerns and practical considerations. Cyberpsychol Behav Soc Netw 2013 Sep;16(9):708-713 [FREE Full text] [doi: 10.1089/cyber.2012.0334] [Medline: 23679571]

33. Van Rode V, Rotsaert M, Delhaye M. [Loneliness and adolescence: clinical implications and outlook. Literature review]. Rev Med Brux 2015;36(5):415-420. [Medline: 26749631]

34. Grist R, Porter J, Stallard P. Mental Health Mobile Apps for Preadolescents and Adolescents: A Systematic Review. J Med Internet Res 2017 May 25;19(5):e176 [FREE Full text] [doi: 10.2196/jmir.7332] [Medline: 28546138]

35. Moreno M, Pumper M. Adolescent Health Displays. In: Rosen LD, Cheever NA, Carrier LM, editors. Wiley Handbook of Psychology, Technology, and Society. Hoboken, NJ: John Wiley \& Sons; 2015:287-300. 


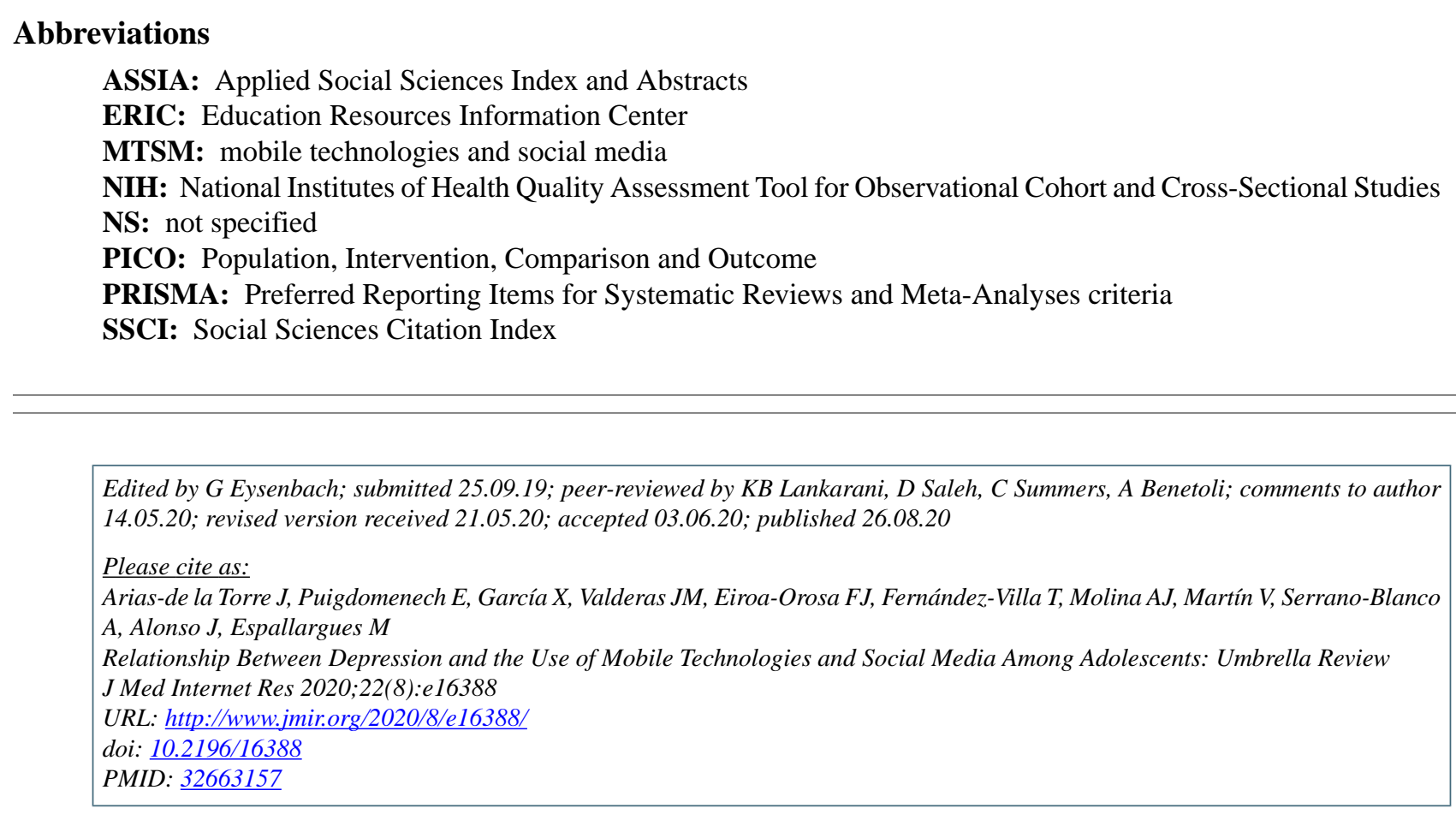

CJorge Arias-de la Torre, Elisa Puigdomenech, Xavier García, Jose M Valderas, Francisco Jose Eiroa-Orosa, Tania Fernández-Villa, Antonio J Molina, Vicente Martín, Antoni Serrano-Blanco, Jordi Alonso, Mireia Espallargues. Originally published in the Journal of Medical Internet Research (http://www.jmir.org), 26.08.2020. This is an open-access article distributed under the terms of the Creative Commons Attribution License (https://creativecommons.org/licenses/by/4.0/), which permits unrestricted use, distribution, and reproduction in any medium, provided the original work, first published in the Journal of Medical Internet Research, is properly cited. The complete bibliographic information, a link to the original publication on http://www.jmir.org/, as well as this copyright and license information must be included. 